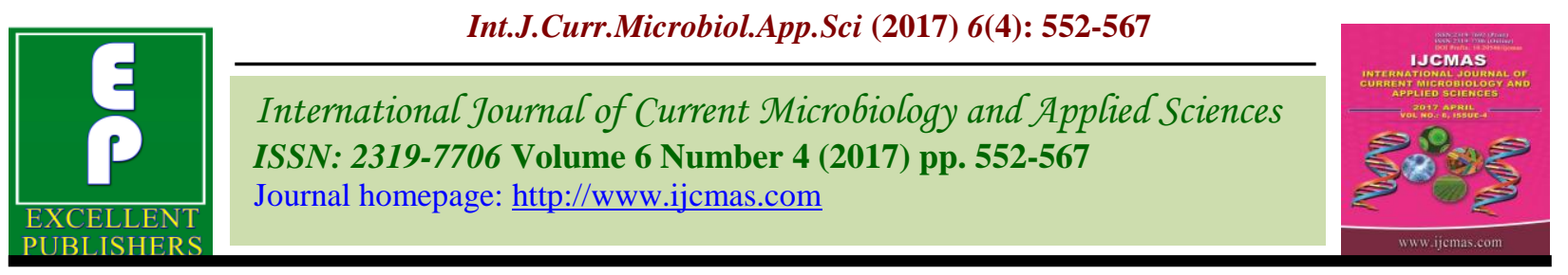

Original Research Article

https://doi.org/10.20546/ijcmas.2017.604.067

\title{
Shelf Life Studies of Buttermilk Supplemented with Moringa
}

\author{
Binjan K. Patel ${ }^{1}$, Sunil M. Patel ${ }^{2}$, Zeel S. Modi ${ }^{3}$ and Suneeta V. Pinto ${ }^{1}$ * \\ ${ }^{1}$ Department of Dairy Technology, SMC College of Dairy Science \\ Anand Agricultural University, Anand-388110 (Gujarat), India \\ ${ }^{2}$ Department of Dairy Engineering, SMC College of Dairy Science \\ Anand Agricultural University, Anand-388110 (Gujarat), India \\ ${ }^{3}$ Department of Dairy Chemistry, SMC College of Dairy Science \\ Anand Agricultural University, Anand-388110 (Gujarat), India \\ *Corresponding author
}

\begin{tabular}{|c|c|}
\hline & A B S T R A C T \\
\hline & \multirow{6}{*}{$\begin{array}{l}\text { In the present study, changes in sensory, physico-chemical characteristics and } \\
\text { microbiological counts of two types of Moringa supplemented buttermilk viz. Moringa } \\
\text { leaf buttermilk (MLBM) and Moringa pod buttermilk (MPBM) and control (C) stored at } \\
5 \pm 2{ }^{0} \mathrm{C} \text { were evaluated on every } 5^{\text {th }} \text { day of storage till the products became unacceptable. } \\
\text { There was a significant }(\mathrm{P}<0.05) \text { increase in acidity in all the samples during storage. The } \\
\text { interaction effect of the treatments with the period was found to be significant }(\mathrm{P}<0.05) \mathrm{pH} \\
\text { values of buttermilks showed gradual decline during storage. Initial } \mathrm{pH} \text { values for control, } \\
\text { MPBM and MLBM was } 4.79,4.74 \text { and } 4.78 \text { which decreased to } 3.49,3.87 \text { and } 3.72 \\
\text { respectively after } 25 \mathrm{~d} \text { of storage. The average soluble nitrogen content }(\%) \text { of control } \\
\text { increased steadily from } 0.310 \text { to } 0.503 \text { within a period of } 25 \mathrm{~d} \text { of storage. Whereas the } \\
\text { respective values for MPBM and MLBM were } 0.253 \text { to } 0.414 \text { and } 0.215 \text { to } 0.313 \\
\text { respectively. Lactobacilli count was significantly lower (P<0.05) in MPBM and MLBM } \\
\text { (4.41 log cfu/g and } 4.26 \text { log cfu/g) as compared to control }(4.48 \text { log cfu/g) in the fresh } \\
\text { product on } 0 \mathrm{~d} \text {. The changes in overall acceptability score of the buttermilk during storage } \\
\text { revealed that the MLBM and MPBM were acceptable even on the } 25^{\text {th }} \mathrm{d} \text { of storage, } \\
\text { indicating its better stability compared to Control which was found to be unacceptable on } \\
\text { the } 20^{\text {th }} \text { day of storage. }\end{array}$} \\
\hline Keywords & \\
\hline $\begin{array}{l}\text { Buttermilk, } \\
\text { Moringa, Moringa } \\
\text { pod, Drumstick, } \\
\text { Chhash, Storage. }\end{array}$ & \\
\hline Article Info & \\
\hline $\begin{array}{l}\text { Accepted: } \\
\text { 04 March } 2017 \\
\text { Available Online: } \\
10 \text { April } 2017\end{array}$ & \\
\hline & \\
\hline
\end{tabular}

\section{Introduction}

Buttermilk is traditionally known as "Chhash" (Gujarat and MP), "Mattha" (UP and Delhi), "Tak" (Maharastra), "Ghol" (Bengal). Chhash is also popular, as sour buttermilk, in several other parts of the world i.e. East Asia, Africa, Europe, etc. Buttermilk has mild pleasing flavour resulting from a blend of clean acid taste and delicate aromatic flavour and it should be free from off flavours like flat, metallic, yeasty or bitterness. The colour of the cultured buttermilk varies from yellowish creamy white for cow milk to creamy white for buffalo milk and should be free from browning and extraneous matter; smooth and glossy appearance of cultured buttermilk is preferred. It should have uniform thick consistency and should be free from churned particles and smooth texture is more preferred (Chandan, 2006). The milk fat and total solids in buttermilk varies between 0.5 to $1.5 \%$ and 
4.5 to $5.5 \%$ respectively. Moringa is very impressive and amazing plant due to its tested, trusted and potential benefits from nutritional as well therapeutical point of views. Moringa can be a good tool to combat not only Vitamin A deficiency, but also other micronutrient deficiency at a global level. Moringa oleifera has numerous medicinal uses, which have long been recognized in the Ayurvedic and Unani systems of medicine (Mughal et al., 1999). Therefore, incorporation of drumstick in buttermilk results in elevating its nutritional and functional value by increasing its iron, vitamin $\mathrm{C}$, calcium, potassium and fiber content.

A significant increase in acidity in the heated $\left(45{ }^{0} \mathrm{C}\right.$ for $30 \mathrm{~min}$ ) samples of dahi was observed during storage while the samples of Dahi subjected to heat treatment at $55{ }^{0} \mathrm{C}$ or $65{ }^{0} \mathrm{C}$ for $30 \mathrm{~min}$ did not show appreciable change in acidity even after one month storage at $30^{\circ} \mathrm{C}$ (Chander, 1989). Different strains of Lactobacillus bulgaricus and Streptococcus thermophilus have been found varying capability to produce acid and varying amount proteolytic activity (Beyatli and Tunali, 1984). Proteolysis in yoghurt prepared from cow and goat milk tended to continue during storage for $15 \mathrm{~d}$ at $4-5{ }^{\circ} \mathrm{C}$ (Kehagias et al., 1987). Protein degradation was found to occur during the storage of the fermented dairy products. The ratio of soluble nitrogen to total nitrogen tended to increase during storage (Fayed et al., 1989). Chander, (1989) observed comparatively less proteolysis during storage of Dahi heat treated at $55{ }^{0} \mathrm{C}$ for $30 \mathrm{~min}$. Patel (1984) noted proteolysis even in yoghurt subjected to post incubation heat treatment $\left(65{ }^{\circ} \mathrm{C} / 5 \mathrm{~min}\right)$. The average value of tyrosine content for unthermized yoghurts increased from 98.6 to 166.9 during 3 weeks of storage period. Chander (1989) observed an increasing trend of FFAs in dahi samples heated at $45{ }^{\circ} \mathrm{C}, 55$ ${ }^{0} \mathrm{C}$ and $65{ }^{\circ} \mathrm{C}$ for $30 \mathrm{~min}$ but showed only a slight increase in the samples heated at $65{ }^{\circ} \mathrm{C}$. The lipolytic activity was found to increase with increase in temperature and duration of storage, which could be attributed to bacterial lipolytic enzymes surviving the heat treatment or those elaborated during storage by the organisms. In fermented product like buttermilk acidity, proteolytic and lipolytic changes during storage can affect the acceptance of the product by consumers. Hence, the study was planned to assess the effect of storage on physico-chemical, microbiological and sensory quality of buttermilk supplemented with Moringa.

\section{Materials and Methods}

Standardized milk $(4.6 \pm 0.2$ / 8.6 $\pm 0.05 \%)$ was used as the base material for preparation of buttermilk. The starter culture used for preparation of dahi was obtained from Christen Hansen Exact Dahi 2- Mat no.706272 (Freeze-dried lactic culture for Direct Vat, Denmark). This culture consists of Mesophilic/Thermophilic culture. Moringa leaf powder (MLP) and Moringa Pod powder (MPP) were procured from Pushpam foods, Kunjrao, Gujarat. The composition of MPP was $2.2 \%$ fat, $16.1 \%$ protein, 7.6 ash, $29.5 \%$ fibre and $1.1 \%$ moisture. The composition of MLP was $1.9 \%$ fat, $22.8 \%$ protein, $5.04 .6 \%$ ash, $3.9 \%$ fibre and $7.5 \%$ moisture. Cane sugar (Madhur Brand, Shri Renuka Sugars Ltd., Karnataka, non-sulphated, refined) of commercial grade and Tata brand (iodized) common salt was used. Two blend of spices consisting of mixture spices viz. Blend A consisting of cumin, dry mango powder, ginger and chilli powder and Blend B consisting of mint, black pepper and chilli powder was used for flavouring in Moringa leaf buttermilk (MLBM), Low methoxy Pectin of Loba chemical, Mumbai and Iota carrageenan of Himedia Laboratories Pvt. Ltd., Mumbai were used as a stabilizer in buttermilk. 


\section{Preparation of Moringa Leaf buttermilk}

The manufacture of MLBM by standardized method was done in two parts. In the first part Moringa leaf base was prepared by weighing the required amount of dried ingredients viz. MLP @ $0.62 \%$, pectin @ $0.08 \%$, carrageenan@0.03\%, sugar @ 4.0\%, salt @ $0.5 \%$, spice mixture @ $0.49 \%$.

All the dried ingredients were calculated on the basis of $\mathrm{w} / \mathrm{w}$ of buttermilk. Calculated amount of potable water $\left(45\right.$ to $\left.50{ }^{0} \mathrm{C}\right)$ to lower down TMS of dahi from $13.0 \%$ to 5.31 percent was taken in a SS vessel. The dry ingredients were added to the water and blended in high speed blender for 2 min and heated to $90{ }^{0} \mathrm{C} /$ no hold followed by immediate cooling to room temperature (35$\left.40{ }^{\circ} \mathrm{C}\right)$.

In the second part of the procedure SPM was taken, then it was pre heated to $35-40{ }^{\circ} \mathrm{C}$, filtered, heated to $90{ }^{\circ} \mathrm{C}$ for $5 \mathrm{~min}$, cooled to $40 \pm 2{ }^{\circ} \mathrm{C}$ and incubated with DVS lactic mesophilic/ thermophilic dahi culture(@ $0.7 \mathrm{~g} / 10 \mathrm{~kg}$ milk) till an acidity of $0.85 \% \mathrm{LA}$ ) was attained. The curd was broken and cooled immediately to $8 \pm 2{ }^{\circ} \mathrm{C}$. After cooling the curd attained the desired final acidity of $0.90 \%$ LA. The Moringa leaf base was added to the dahi and blended for 30-40 s in a mixer at low speed. Finally, for proper blending product was heated to $60{ }^{\circ} \mathrm{C}$ and subjected to low pressured homogenization at $25 \mathrm{~kg} / \mathrm{cm}^{2}$ followed by thermization at $65{ }^{\circ} \mathrm{C}$ for $5 \mathrm{~min}$ and filling in pre sterilized PET bottles and stored at $5 \pm 2{ }^{\circ} \mathrm{C}$.

\section{Preparation of Moringa pod buttermilk}

The manufacture of MPBM by standardized method was done in two parts. In the first part, Moringa pod base was prepared by weighing the required amount of dried ingredients viz. MPP @ $1.92 \%$, pectin @ $0.04 \%$, carrageenan@ 0.015\%, sugar@ 4.0
\%, salt @ $0.5 \%$, spice mixture @ $0.49 \%$. All the dried ingredients were calculated on the basis of w/w of buttermilk. Calculated amount of potable water $\left(45\right.$ to $\left.50{ }^{\circ} \mathrm{C}\right)$ to lower down TMS of dahi from $13.0 \%$ to 5.60 percent was taken in a SS vessel. The dry ingredients were added to the water and blended in high speed blender for 2 min and heated to $90{ }^{\circ} \mathrm{C} /$ no hold followed by immediate cooling to room temperature $\left(35-40{ }^{\circ} \mathrm{C}\right)$. In the second part of the procedure SPM was taken, then it was pre heated to $35-40{ }^{\circ} \mathrm{C}$, filtered, heated to $90{ }^{\circ} \mathrm{C}$ for $5 \mathrm{~min}$, cooled to $40 \pm 2{ }^{\circ} \mathrm{C}$ and incubated with DVS lactic mesophilic/ thermophilic dahi culture(@0.7g/10 kg milk) till an acidity of $0.85 \%$ LA) was attained.

The curd was broken and cooled immediately to $8 \pm 2{ }^{\circ} \mathrm{C}$. After cooling the curd attained the desired final acidity of $0.90 \%$ LA. The Moringa pod base was added to the dahi and blended for 30-40 s in a mixer at low speed. Finally, for proper blending product was heated to $60{ }^{\circ} \mathrm{C}$ and subjected to low pressure homogenization at $25 \mathrm{~kg} / \mathrm{cm}^{2}$ followed by thermization at $65{ }^{\circ} \mathrm{C}$ for $5 \mathrm{~min}$ and filling in pre sterilized PET bottles and stored at $5 \pm 2$ ${ }^{0} \mathrm{C}$.

During storage various physic0-chemical changes occurring in the two types of Moringa buttermilks were monitored on every $5^{\text {th }} \mathrm{d}$ of storage or till the product was rejected on sensory ground and compared with control (when the score reaches 6.0 or less on hedonic scale) or till it became unacceptable. Control was prepared according to the method standardized by Rao (2003).

\section{Physico-chemical analysis}

The experimental samples of buttermilks were analyzed for total solids (TS), protein, fat and ash as per methods advocated by Bureau of Indian standards (BIS, 1989). Soluble nitrogen content was estimated by the method 
outlined by Kosikowski (1982). The free fatty acids content in product sample was determined by the method described by Deeth and Fitz-Gerald (1976). pH of sample was measured by used of Electronic $\mathrm{pH}$ meter (Model CYBERSCAN 2100 manufactured by EUTECH Instruments, Singapore). Iron concentration of was estimated by atomic absorption spectrophotometry (Spectrophotometer - Perkin Elmer model $3110), \lambda=248.3 \mathrm{~nm}$. The calcium content of product was measured according to method given by BIS (SP: 18 (Part XI) 1989). Vitamin A was analyzed using the standard procedure of AOAC (2004). Potassium content was analyzed by using the standard procedure of AOAC (2004). Vitamin C estimation was carried out by procedure described as per BIS Hand Book (1989). The Crude Fibre content of buttermilk was determined by the method described in BIS Handbook (1989) using 2 g sample.

\section{Microbiological analysis}

For microbiological analysis (for lactobacilli, SPC, yeast and mold and coliforms) $11 \mathrm{~g}$ of sample was diluted in $99 \mathrm{ml}$ phosphate buffer according to method described in IS: 1479 (1961). Further serial dilutions were prepared in $9 \mathrm{ml}$ phosphate buffer. One $\mathrm{ml}$ each from two or three suitable dilutions was poured with either acidified MRS agar. The plates were allowed to solidify and then layered with 6-7 $\mathrm{ml}$ of the same agar. Number of colonies developed were counted after incubating plates at $37{ }^{\circ} \mathrm{C}$ for $48 \mathrm{~h}$ and expressed as cfu of lactobacilli/g. The methods of plating, incubation and counting for the enumeration of SPC, yeasts and molds as well as coliforms were followed as described by BIS (1989 (Part XI)).

\section{Sensory evaluation}

The Moringa buttermilks were analyzed for sensory characteristics by a panel of ten trained judges using 9-point hedonic scale. The products were judged for flavour, body (consistency), colour and appearance, acidity score and overall acceptability.

\section{Statistical analysis}

Statistical analysis of data was carried out using Completely Randomized Design (Steel and Torrie 1980).

\section{Results and Discussion}

\section{Changes in sensory attributes}

The most affected sensory attribute is flavour. The changes in flavour score during storage of control and experimental samples of buttermilk (MPBM and MLBM) are presented in table 1. In case of Control, the flavour score decreased from the initial value of $8.52 \pm 0.13$ to $7.72 \pm 0.10$ (on the $5^{\text {th }} \mathrm{d}$ ) and further decreased to $5.52 \pm 0.08$ (on the $20^{\text {th }} \mathrm{d}$ ) and on which the judging panel rejected it. The pertinent statistical analysis revealed that type of buttermilk as well as storage period had significant $(\mathrm{P}<0.05)$ effect on the flavour scores of buttermilk. The interaction between type of buttermilk $(\mathrm{T})$ and storage period $(\mathrm{P})$ was statistically significant $(\mathrm{P}<0.05)$ for changes in flavour score of buttermilk over the storage period. In case of buttermilks containing Moringa, the flavour scores were found acceptable even on the $25^{\text {th }} \mathrm{d}$ of storage. The samples were noticed to develop slight staleness and slight ethereal smell on the $25^{\text {th }} \mathrm{d}$ of storage, hence the study was discontinued. The changes in flavour score of the buttermilk during storage revealed that the MLBM and MPBM were acceptable even on the $25^{\text {th }} \mathrm{d}$ of storage, indicating its better stability compared to $\mathrm{C}$. The reason for sharp decrease in flavour score of the $\mathrm{C}$ was attributed to undesirable flavour and higher acidity. A significant $(\mathrm{P}<0.05)$ decrease in consistency was found on $20^{\text {st }} \mathrm{d}$ of storage resulting in decreased body scores. Thereafter 
a significant $(\mathrm{P}<0.05)$ decrease observed up to $25 \mathrm{~d}$ of storage in both the products. Statistically the interaction effect of the treatments with the period was significant $(\mathrm{P}<0.05)$. The decrease in body and texture score of the buttermilks might be attributed to physicochemical changes taking place in the product during the storage. It is reported that buttermilk typically has a thick, homogeneous body. Some of the known culture-related defects will eventually lead to body and texture defects. For example, if the culture lacks adequate activity and if the product is cooled at low acidity, the finished product will not have optimum viscosity. Some contaminants produce slime, which results in a highly viscous product (Mistry, 2001). Therefore, reduction in body score of buttermilks may be attributed to such reasons as discussed above. However no research has been reported in literature on the changes in body scores in Moringa buttermilk during storage for comparison.

Statistically there was significant $(\mathrm{P}<0.05)$ difference found in colour and appearance score due to the control and treatment. Apparently the score for Control was higher than the MPBM and MLBM during the storage period owing to the green colour imparted by the MLP and caramel colour imparted by MPP. Statistically significant difference $(\mathrm{P}<0.05)$ in colour and appearance score in all the three products was found during the storage of $25 \mathrm{~d}$. The score significantly decreased on $5^{\text {th }}, 10^{\text {th }}, 15^{\text {th }}$ and $20^{\text {th }} \mathrm{d}$ of storage. Thereafter the decrease in colour and appearance score was significant $(\mathrm{P}<0.05)$ in all the three products. The interaction effect of the treatments with the period showed significant $(\mathrm{P}<0.05)$ difference in the scores. The decrease in colour score may be due to the degradation of chlorophyll during the storage. The decrease in colour and appearance score of the cultured buttermilks might be attributed to associated physicochemical changes taking place in product during storage. The chlorophyll content of MLP is responsible for the greenish colour in the product. However the greenish colour of the fresh product got more acceptability than the control by the panelists and during storage the colour score decreased due to loss of greenish tinge in MLBM.

The pertinent statistical analysis revealed that type of buttermilk as well as storage period had significant $(\mathrm{P}<0.05)$ effect on the acidity scores of buttermilk. The interaction between type of buttermilk $(\mathrm{T})$ and storage period $(\mathrm{P})$ was statistically significant $(\mathrm{P}<0.05)$ for changes in flavour score of buttermilk over the storage period. Moreover, the difference in flavour score of the butter milk prepared with Moringa (MLBM) remained significantly $(\mathrm{P}<0.05)$ higher compared other two types of buttermilk. In case of buttermilks containing Moringa, the acidity scores were found acceptable even on the $20^{\text {th }} \mathrm{d}$ of storage. The samples were noticed to develop slight acidic sour smell on the $25^{\text {th }} \mathrm{d}$ of storage, hence the study was discontinued. From the results obtained during the course of this investigation, it can be seen that the acidity score of experimental buttermilks decreased steadily up to $20^{\text {th }} \mathrm{d}$ and thereafter there was steep decrease on the $25^{\text {th }} \mathrm{d}$. The changes in acidity score of the buttermilk during storage revealed that the MLBM and MPBM were acceptable even on the $25^{\text {th }} \mathrm{d}$ of storage, indicating its better stability compared to Control buttermilk $\left(15^{\text {th }} \mathrm{d}\right)$. The reason for sharp decrease in acidity score of the Control buttermilk was attributed to progressive decrease in $\mathrm{pH}$ and increase in acidity during storage.

There was significant $(\mathrm{P}<0.05) \quad$ decrease observed in overall acceptability score during the storage. The decrease in score was found to be significant $(\mathrm{P}<0.05)$ for all the products. The significant difference in score obtained 
from $0 \mathrm{~d}$ to $10 \mathrm{~d}$ of storage in control whereas non-significant for the Moringa products. The interaction effect of the treatments with the period also showed significant $(\mathrm{P}<0.05)$ changes. The overall acceptability of MLBM with MPBM was statistically at par. The main reason for sharp decrease in overall acceptability score of the buttermilks with was attributed to deterioration of flavour. The other reason was undesirable changes in body of the product. According to sensory profile, the Moringa product was better or at par in terms of different attribute throughout the storage period compared to control. Based on the sensory attributes studied during storage, Moringa buttermilk showed a slight improvement in terms of acceptability compared to control during storage. It can be concluded from this Section that $C$ had a shelf life of $15 \mathrm{~d}$ whereas MPBM and MLBM had a shelf life of $25 \mathrm{~d}$ when stored in PET bottles, the improvement in shelf life in Moringa buttermilk could be attributed to the significant reduction in SPC count (Table 3) in MPBM and MLBM compared to control during the entire storage period. The increased shelf life in Moringa buttermilk could also be attributed to the antioxidant and anti-bacterial properties of Moringa. Vanajakshi et al., (2015) found that fermented beverage containing Moringa had showed antibacterial activity and also exhibited radical scavenging activity. Nadeem et al., (2013) evaluated the antioxidant potential of a Leaf Extract of Moringa oleifera (LEMO) for the stabilization of butter at refrigeration temperature and suggested that LEMO at 600 ppm may be used for reasonable storage stability of butter at refrigeration temperature with acceptable sensory characteristics. Therefore, the results obtained in this study are in accordance with those reported in literature. However no research has been reported in literature on the shelf life of Moringa buttermilk during storage for comparison.

\section{Physico-chemical changes in buttermilks during storage}

Moringa was added as an ingredient in manufacture of Moringa buttermilks. Moringa leaf is rich in vitamins and phenolic compounds including phenolic acids and flavonoids (Makkar and Becker, 1996; Coppin et al., 2013). The leaves of Moringa oleifera contain up to $8 \%$ antioxidants on dry matter basis (Anwar et al., 2006). The antioxidant functionality of this phytochemicals can influence the physicochemical changes taking place in buttermilk during storage. Hence, the fresh and stored experimental samples and control were monitored for physico-chemical changes viz. titratable acidity, $\mathrm{pH}, \mathrm{FFA}$ and soluble nitrogen during and at an interval of every $5^{\text {th }}$ $\mathrm{d}$ during storage at refrigeration conditions i.e. $5 \pm 2{ }^{0} \mathrm{C}$

\section{Titratable acidity}

The changes in titratable acidity (\% LA) of control (C), MPBM and MLBM (T) stored at refrigerated temperature are presented in table 2. During refrigerated storage, titratable acidity gradually increased from 0.33 to 0.64 \% LA in control whereas 0.36 to $0.51 \%$ in MPBM and 0.32 to $0.45 \%$ LA in MLBM. Statistically there was a significant $(\mathrm{P}<0.05)$ increase in acidity during storage. Comparing the treatment and period means, control and Moringa buttermilks both showed significant $(\mathrm{P}<0.05)$ increase in titratable acidity till $25^{\text {th }}$ $\mathrm{d}$ of storage. However significant increase in acidity was found up to $10^{\text {th }} \mathrm{d}$ against the fresh or $0 \mathrm{~d}$ for both the products. The interaction effect of the treatments with the period showed statistically significant $(\mathrm{P}<0.05)$ changes. The progressive increase in titratable acidity during storage may be due to increase in number of organisms and the use of sugar in the experimental samples. Rao (2003) reported an increase in acidity in 
buttermilk samples during storage at refrigeration temperatures from an initial value of $0.60 \%$ LA to $0.79 \%$ LA on $12^{\text {th }} \mathrm{d}$ of storage. Therefore, the results are in line of this study that titratable acidity increase during the refrigerated storage period. However, the values obtained for acidity in $\mathrm{C}$ as well as Moringa buttermilks in this study are much lower than those reported by Rao (2003). The differences in acidity could be attributed to the differences in the initial acidity of dahi as well as ingredients used in the products. However, no research has been reported in literature on the changes in acidity of Moringa buttermilk during storage for comparison.

\section{pH}

$\mathrm{pH}$ values of buttermilks showed gradual decline during the storage at $5 \pm 2{ }^{0} \mathrm{C}$ (Table 2). Initial $\mathrm{pH}$ values for control, MPBM and MLBM was $4.79,4.74$ and 4.78 which decreased to $3.49,3.87$ and 3.72 respectively after $25 \mathrm{~d}$ of storage. Statistically significant decrease $(\mathrm{P}<0.05)$ occurred in control than the product throughout the storage. This was expected as the addition of MLBM inhibited the growth of bacteria owing to its antioxidant capacity, which retard the acid production rate in the product; hence lesser decrease in $\mathrm{pH}$ was obvious. Comparing $\mathrm{CD}$ value for period means, the $\mathrm{pH}$ values of both the products showed significant decrease from $0 \mathrm{~d}$ up to 10 $\mathrm{d}$ and thereafter $15 \mathrm{~d}$ decrease till $25^{\text {th }} \mathrm{d}$. Rao (2003) reported a decrease in $\mathrm{pH}$ in buttermilk samples during storage at refrigeration temperatures from an initial value of 4.14 to 4.11 on the $12^{\text {th }} \mathrm{d}$ of storage. Therefore, the results are in line of this study that $\mathrm{pH}$ decrease during the refrigerated storage period. However, the values obtained for $\mathrm{pH}$ in $\mathrm{C}$ as well as Moringa buttermilks in this study are higher than those reported by Rao (2003). The differences in $\mathrm{pH}$ could be attributed to the differences in the initial acidity of dahi as well as ingredients used in the products. However, no research has been reported in literature on the changes in $\mathrm{pH}$ of Moringa buttermilk during storage for comparison.

\section{Free fatty acids}

There was significant increase $(\mathrm{P}<0.05)$ in control, MPBM and MLBM sample from fresh or $0 \mathrm{~d}$ to $25^{\text {th }} \mathrm{d}$ (Table 2). Statistically there was significant $(\mathrm{P}<0.05)$ between control and treatment with respect to change in free fatty acid content. However there was non-significant $\quad(\mathrm{P}<0.05)$ between the Moringa buttermilks. The interaction effect of the treatments with the period also showed significant $(\mathrm{P}<0.05)$ effect. While comparing period means it showed that free fatty acid content was not significantly increased till $25^{\text {th }} \mathrm{d}$ of refrigerated storage. The free fatty acid content in the products was increased gradually till the end of storage which suggests that the chemical deterioration occurred in the products during storage and steep increase in free fatty acid was observed in control sample occurred after $5^{\text {th }} \mathrm{d}$ of storage. Whereas in experimental samples containing Moringa, similar behavior was observed after $15^{\text {th }} d$ of storage. Rao (2003) reported an increase in FFA in buttermilk samples during storage at refrigeration temperatures from an initial value of 0.120 to 0.137 on the $12^{\text {th }} \mathrm{d}$ of storage. Therefore, the results are in line of this study that FFA increase during the refrigerated storage period. However, the values obtained for FFA in Moringa buttermilks in this study are lower than those reported by Rao (2003). The differences in FFA could be attributed to the lower SPC count observed in Moringa buttermilks throughout storage compared to control as well as antibacterial and antioxidant activity of Moringa (Nadeem et al., 2013; Vanajakshi et al., 2015) ingredients used in the products. However, no research has been reported in literature on the changes 
in FFA of Moringa buttermilk during storage for comparison.

\section{Proteolytic changes}

The amount of soluble nitrogenous compound increases when milk is cultured with yoghurt organisms, signifying the proteolytic activity of the organisms (Tamime and Deeth, 1980). Even in post incubation heat treated dahi samples, the proteolytic changes have been reported (Chander, 1989), which may be attributed to the bacterial enzymes liberated before the heat treatment and surviving thermal processing. The excessive hydrolysis of milk proteins may lead to bitter flavour and/or gelation. Hence the soluble nitrogen content of buttermilk was monitored during storage.

The proteolytic behavior of control, and experimental samples of buttermilk containing Moringa and subsequently stored at $5 \pm 2{ }^{0} \mathrm{C}$ is presented in table 2 . The milk used to make dahi was observed to contain an average of $0.23 \%$ soluble nitrogen, while, the soluble nitrogen of control buttermilk at $0 \mathrm{~d}$ was found to be $0.310 \%$. Whereas, the initial values for MLBM and MPBM were much lower i.e. 0.253 and 0.215 respectively than C. This effect could be attributed to lower TMS content in MPBM (5.59) and MLBM (5.31). Thus the cultured organisms were observed to produce large quantity of soluble nitrogen during incubation period. It can be seen from table 2, the average soluble nitrogen content $(\%)$ of control increased steadily from 0.310 to 0.503 within a period of $25 \mathrm{~d}$ of storage. Whereas the respective values for MPBM and MLBM were 0.253 to 0.414 and 0.215 to 0.313 respectively indicating slower rate of soluble nitrogen production in Moringa buttermilks. The soluble nitrogen $\%$ of control was found to be 0.440 (on $15^{\text {th }} \mathrm{d}$ ) before the rejection on $15^{\text {th }} \mathrm{d}$ of storage. Similar results were obtained by
Rao (2003), when studying the effect of storage of chhash at refrigeration temperature. Whereas for experimental samples MPBM and MLBM, the soluble nitrogen content was found to be 0.403 and 0.303 respectively on the $20^{\text {th }} \mathrm{d}$ of storage i.e. the day when the samples were rejected on the basis of sensory analysis.

It is evident from these observations that proteolytic changes occur during storage of all the types of buttermilks. The values obtained during this investigation were marginally higher in case of control compared to samples containing Moringa, this may be attributed to the differences in SPC and LAB. Secondly, the rate of proteolytic activity (soluble nitrogen was found maximum in case control and minimum in case of MLBM). The overall increase, though at a slower rate, insoluble nitrogen content in buttermilk samples containing observed during storage in this study may be ascribed to the fact that metabolic activity of LAB, is considerably reduced by presence of certain constituents in Moringa, but their cellular enzyme activity may not be completely arrested. The probable presence of proteolytic might have been contributed by survived starter bacteria and other proteolytic organisms; and/or by proteolytic enzymes surviving the post incubation heat treatment. An increase in lactic organisms and SPC was observed in this study, which further supports the results obtained during this investigation.

However, the factors related with the pattern of growth of microbes, their metabolites produced may also be considered for this effect noticed during storage. In the present investigation, all the buttermilks were criticized for slight bitterness at the point of rejection by the judges, which may be due to residual protease activity, releasing some bitter peptides. 
Tyrosine value indicates the proteolytic action of cultures in the product. The proteolytic activity releases tyrosine which acts as an indicator of chemical deterioration of product. The results obtained in this study are in agreement with those obtained by Gawai (2006), who reported that tyrosine value which was in the range of 0.092 (plain dahi) to 0.195 (symbiotic dahi with sugar) for fresh product which later on increased and was in range of 0.18 (plain dahi) to 0.272 (symbiotic dahi with sugar) after $28 \mathrm{~d}$ of storage. However, no research has been reported in literature on the changes in soluble nitrogen of Moringa buttermilk during storage for comparison.

\section{Microbiological changes in buttermilks during storage}

Since fermented dairy products contain live microorganisms, they are prone to have limited shelf life. Therefore, in order to prolong their shelf life, the product is subjected to thermization. By heat treating cultured milks, it is possible to check growth of lactic bacteria, as well as to destroy the contaminants, initially present in the base product or those contaminated during processing operations. However the growth of survivors and contaminants may be possible even in heat treated buttermilk and hence limit the shelf life of such products, therefore the microbiological quality of fresh as well as product stored at refrigeration temperature, were assessed by enumerating Lactic acid bacteria (LAB), Standard plate count (SPC), Yeast and Mold count ( $\mathrm{Y}$ and $\mathrm{M}$ ) and Coliform count till the control and experimental buttermilks viz. MLBM and MPBM were observed to spoil or were rejected by the judging panel.

\section{Coliform count}

The coliform count of buttermilks was done in fresh as well as stored product. It was found that during entire course of study, the coliforms in product initially, as well as during all the intervals at refrigerated storage period were absent in $1 \mathrm{ml}$ product. Coliforms are not the primary cause of spoilage of fermented milk and their presence in this type of product is rarely possible. However, their presence in fermented milk depends on the extent of hygienic conditions maintained, initial acidity of the product and the type of culture used. It was reported that coliforms cannot survive in acidic products and also the antagonistic effect of starter culture do not permit them to survive (Dave, 1991).

Coliforms are opportunistic pathogens, which generally indicate hygiene and post pasteurization contamination. Their presence in fermented milk depends on the type of culture used for product manufacturing as well as the initial acidity of the product. Dave (1991) reported that coliforms are not able to thrive in acidic products; moreover the antagonistic effects of starter cultures inhibit their growth. Coliform count was estimated by pour plate method using violet red bile agar (VRBA). Coliform was found to be absent (in $1 \mathrm{~g}$ ) in both control sample buttermilk without Moringa and buttermilk with Moringa throughout the storage study of $28 \mathrm{~d}$. The products manufactured in the present study were made under hygienic conditions in laboratory and hence coliforms were not detected in the products.

\section{Yeast and mold count}

The changes in yeast and mold count (cfu/g) of $\mathrm{C}$ and Moringa buttermilks stored at refrigerated temperature are measured. The product showed absent of yeast and mold in 1 $\mathrm{ml}$ samples throughout the storage period of 15 and $25 \mathrm{~d}$ respectively. It indicates the good hygienic condition and no aerial contamination of product in initial as well as storage period. 
Table.1 Changes in sensory scores of Moringa buttermilks stored at $7 \pm 2{ }^{0} \mathrm{C}$

\begin{tabular}{|c|c|c|c|c|c|c|c|}
\hline \multirow{2}{*}{$\begin{array}{l}\text { Treatments } \\
\text { (T) }\end{array}$} & \multicolumn{6}{|c|}{ Storage period in days $(\mathbf{P})$} & \multirow{2}{*}{$\begin{array}{l}\text { Average for } \\
\text { Treatment }(T)\end{array}$} \\
\hline & 0 & 5 & 10 & 15 & 20 & 25 & \\
\hline \multicolumn{8}{|c|}{ Flavour Score } \\
\hline Control & $8.52 \pm 0.13$ & $7.72 \pm 0.10$ & $6.82 \pm 0.08$ & $6.15 \pm 0.05$ & $5.52 \pm 0.08$ & $4.33 \pm 0.42$ & 6.51 \\
\hline MLBM & $8.34 \pm 0.05$ & $8.18 \pm 0.03$ & $8.07 \pm 0.06$ & $7.97 \pm 0.06$ & $7.77 \pm 0.15$ & $6.33 \pm 0.10$ & 7.78 \\
\hline MPBM & $8.22 \pm 0.11$ & $8.07 \pm 0.06$ & $7.97 \pm 0.06$ & $7.87 \pm 0.06$ & $7.77 \pm 0.06$ & $6.35 \pm 0.10$ & 7.71 \\
\hline $\begin{array}{l}\text { Average for } \\
\operatorname{Period}(P)\end{array}$ & 8.36 & 7.99 & 7.62 & 7.33 & 7.02 & 5.67 & \\
\hline \multicolumn{8}{|c|}{$\mathrm{CD}(0.05) \quad T=0.09 ; P=0.12 ; T \times P=0.21$} \\
\hline \multicolumn{8}{|c|}{ Body (Consistency) Score } \\
\hline Control & $8.37 \pm 0.15$ & $7.83 \pm 0.15$ & $7.67 \pm 0.21$ & $7.47 \pm 0.12$ & $7.17 \pm 0.15$ & $6.87 \pm 0.06$ & 7.56 \\
\hline MLBM & $8.33 \pm 0.04$ & $8.18 \pm 0.03$ & $8.11 \pm 0.10$ & $7.97 \pm 0.06$ & $7.79 \pm 0.15$ & $7.37 \pm 0.15$ & 7.95 \\
\hline МРBM & $8.18 \pm 0.05$ & $8.07 \pm 0.06$ & $7.97 \pm 0.06$ & $7.87 \pm 0.06$ & $7.73 \pm 0.06$ & $7.30 \pm 0.10$ & 7.86 \\
\hline $\begin{array}{l}\text { Average for } \\
\operatorname{Period}(\mathbf{P})\end{array}$ & 8.29 & 8.03 & 7.91 & 7.77 & 7.57 & 7.18 & \\
\hline \multicolumn{8}{|c|}{$\mathrm{CD}(\mathbf{0 . 0 5}) \quad \mathrm{T}=0.07 ; \mathrm{P}=0.11 ; \mathrm{TxP}=0.18$} \\
\hline \multicolumn{8}{|c|}{ Colour and Appearance Score } \\
\hline Control & $8.30 \pm 0.17$ & $8.19 \pm 0.14$ & $8.07 \pm 0.11$ & $7.95 \pm 0.09$ & $7.84 \pm 0.07$ & $7.72 \pm 0.05$ & 8.01 \\
\hline MLBM & $8.11 \pm 0.10$ & $8.01 \pm 0.10$ & $7.93 \pm 0.11$ & $7.82 \pm 0.11$ & $7.65 \pm 0.09$ & $7.55 \pm 0.09$ & 7.85 \\
\hline MPBM & $8.15 \pm 0.02$ & $8.07 \pm 0.06$ & $7.98 \pm 0.07$ & $7.89 \pm 0.08$ & $7.80 \pm 0.10$ & $7.64 \pm 0.16$ & 7.92 \\
\hline $\begin{array}{l}\text { Average for } \\
\operatorname{Period}(\mathbf{P})\end{array}$ & 8.19 & 8.09 & 7.99 & 7.89 & 7.76 & 7.64 & \\
\hline
\end{tabular}




\begin{tabular}{|c|c|c|c|c|c|c|c|}
\hline CD (0.05) & \multicolumn{7}{|c|}{$\mathrm{T}=0.07 ; \mathrm{P}=0.10 ; \mathrm{TxP}=0.17$} \\
\hline \multicolumn{8}{|c|}{ Acidity Score } \\
\hline Control & $8.42 \pm 0.03$ & $7.72 \pm 0.10$ & $6.82 \pm 0.08$ & $6.15 \pm 0.05$ & $5.52 \pm 0.08$ & $4.33 \pm 0.42$ & 6.49 \\
\hline MLBM & $8.40 \pm 0.05$ & $8.21 \pm 0.05$ & $8.11 \pm 0.02$ & $7.97 \pm 0.06$ & $7.80 \pm 0.17$ & $6.39 \pm 0.13$ & 7.81 \\
\hline МРBM & $8.20 \pm 0.05$ & $8.07 \pm 0.06$ & $7.97 \pm 0.06$ & $7.87 \pm 0.06$ & $7.75 \pm 0.09$ & $6.35 \pm 0.10$ & $8.20 \pm 0.05$ \\
\hline $\begin{array}{l}\text { Average for } \\
\operatorname{Period}(P)\end{array}$ & 8.34 & 8.00 & 7.63 & 7.33 & 7.02 & 5.69 & \\
\hline \multicolumn{8}{|c|}{$T=0.08 ; P=0.12 ; T x P=0.20$} \\
\hline \multicolumn{8}{|c|}{ Overall Acceptability Score } \\
\hline Control & $8.15 \pm 0.05$ & $7.75 \pm 0.05$ & $6.82 \pm 0.08$ & $6.15 \pm 0.05$ & $5.52 \pm 0.08$ & $4.33 \pm 0.42$ & 6.45 \\
\hline MLBM & $8.26 \pm 0.10$ & $8.13 \pm 0.08$ & $8.06 \pm 0.05$ & $7.97 \pm 0.06$ & $7.77 \pm 0.15$ & $6.33 \pm 0.10$ & 7.75 \\
\hline MPBM & $8.16 \pm 0.04$ & $8.11 \pm 0.02$ & $7.97 \pm 0.06$ & $7.87 \pm 0.06$ & $7.77 \pm 0.06$ & $6.35 \pm 0.10$ & 7.70 \\
\hline $\begin{array}{l}\text { Average for } \\
\operatorname{Period}(\mathbf{P})\end{array}$ & 8.19 & 8.00 & 7.61 & 7.33 & 7.02 & 5.67 & \\
\hline \multicolumn{8}{|c|}{$T=0.08 ; P=0.12 ; T x P=0.20$} \\
\hline \multicolumn{8}{|c|}{ Acidity (per cent LA) } \\
\hline Control & $0.33 \pm 0.01$ & $0.36 \pm 0.01$ & $0.41 \pm 0.02$ & $0.51 \pm 0.01$ & $0.60 \pm 0.01$ & $0.64 \pm 0.01$ & 0.47 \\
\hline MLBM & $0.32 \pm 0.02$ & $0.35 \pm 0.02$ & $0.38 \pm 0.03$ & $0.40 \pm 0.03$ & $0.43 \pm 0.02$ & $0.45 \pm 0.03$ & 0.39 \\
\hline МPBM & $0.36 \pm 0.01$ & $0.40 \pm 0.01$ & $0.43 \pm 0.02$ & $0.45 \pm 0.02$ & $0.47 \pm 0.01$ & $0.51 \pm 0.02$ & 0.44 \\
\hline $\begin{array}{l}\text { Average for } \\
\operatorname{Period}(P)\end{array}$ & 0.34 & 0.37 & 0.40 & 0.45 & 0.50 & 0.53 & \\
\hline \multicolumn{8}{|c|}{$T=0.01 ; P=0.02 ; T x P=0.03$} \\
\hline
\end{tabular}


Table.2 Storage related physico chemical changes in Moringa buttermilks

\begin{tabular}{|c|c|c|c|c|c|c|c|}
\hline \multirow{2}{*}{$\begin{array}{l}\text { Treatments } \\
\text { (T) }\end{array}$} & \multicolumn{6}{|c|}{ Storage period in days $(\mathrm{P})$} & \multirow{2}{*}{$\begin{array}{l}\text { Average for } \\
\text { Treatment(T) }\end{array}$} \\
\hline & 0 & 5 & 10 & 15 & 20 & 25 & \\
\hline \multicolumn{8}{|l|}{ pH } \\
\hline Control & $4.79 \pm 0.02$ & $4.52 \pm 0.08$ & $4.05 \pm 0.06$ & $3.90 \pm 0.02$ & $3.82 \pm 0.02$ & $3.49 \pm 0.03$ & 4.10 \\
\hline MLBM & $4.80 \pm 0.04$ & $4.39 \pm 0.04$ & $4.05 \pm 0.04$ & $3.95 \pm 0.01$ & $3.84 \pm 0.03$ & $3.72 \pm 0.03$ & 4.12 \\
\hline MPBM & $4.74 \pm 0.08$ & $4.32 \pm 0.06$ & $4.05 \pm 0.03$ & $3.94 \pm 0.05$ & $3.90 \pm 0.05$ & $3.87 \pm 0.03$ & 4.14 \\
\hline $\begin{array}{l}\text { Average for } \\
\text { Period(P) }\end{array}$ & 4.78 & 4.41 & 4.05 & 3.93 & 3.85 & 3.69 & \\
\hline \multicolumn{8}{|c|}{$\mathrm{T}=0.03 ; \mathrm{P}=0.04 ; \mathrm{TxP}=0.07$} \\
\hline \multicolumn{8}{|l|}{ FFA $(\mu \mathrm{eq} / \mathrm{g})$} \\
\hline Control & $0.125 \pm 0.005$ & $0.128 \pm 0.003$ & $0.140 \pm 0.003$ & $0.14 \pm 0.005$ & $0.160 \pm 0.002$ & $0.168 \pm 0.003$ & 0.145 \\
\hline MLBM & $0.082 \pm 0.001$ & $0.091 \pm 0.001$ & $0.098 \pm 0.002$ & $0.102 \pm 0.003$ & $0.112 \pm 0.002$ & $0.127 \pm 0.002$ & 0.102 \\
\hline МРВМ & $0.087 \pm 0.001$ & $0.093 \pm 0.001$ & $0.098 \pm 0.001$ & $0.102 \pm 0.002$ & $0.119 \pm 0.002$ & $0.131 \pm 0.002$ & 0.105 \\
\hline $\begin{array}{l}\text { Average for } \\
\text { Period(P) }\end{array}$ & 0.098 & 0.104 & 0.112 & 0.118 & 0.130 & 0.142 & \\
\hline \multicolumn{8}{|c|}{$T=0.04 ; P=0.03 ; T x P=0.02$} \\
\hline \multicolumn{8}{|c|}{ Soluble Nitrogen(per cent) } \\
\hline Control & $0.312 \pm 0.002$ & $0.374 \pm 0.006$ & $0.401 \pm 0.001$ & $0.440 \pm 0.011$ & $0.497 \pm 0.006$ & $0.503 \pm 0.006$ & 0.421 \\
\hline MLBM & $0.215 \pm 0.004$ & $0.231 \pm 0.002$ & $0.253 \pm 0.002$ & $0.273 \pm 0.002$ & $0.303 \pm 0.003$ & $0.313 \pm 0.003$ & 0.265 \\
\hline МРBM & $0.253 \pm 0.003$ & $0.281 \pm 0.004$ & $0.323 \pm 0.002$ & $0.364 \pm 0.003$ & $0.403 \pm 0.002$ & $0.413 \pm 0.003$ & 0.339 \\
\hline $\begin{array}{l}\text { Average for } \\
\text { Period(P) }\end{array}$ & 0.260 & 0.295 & 0.326 & 0.359 & 0.401 & 0.410 & \\
\hline \multicolumn{8}{|c|}{$T=0.03 ; P=0.04 ; T x P=0.07$} \\
\hline
\end{tabular}


Table.3 Microbiological changes in Moringa buttermilks during storage

\begin{tabular}{|c|c|c|c|c|c|c|c|}
\hline \multirow{2}{*}{$\begin{array}{l}\text { Treatments } \\
\text { (T) }\end{array}$} & \multicolumn{6}{|c|}{ Storage period in days $(P)$} & \multirow{2}{*}{$\begin{array}{l}\text { Average for } \\
\text { Treatment(T) }\end{array}$} \\
\hline & 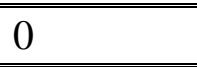 & 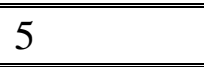 & 10 & 15 & 20 & 25 & \\
\hline \multicolumn{8}{|c|}{ LAB Count $(\log$ cfu/g) } \\
\hline Control & $4.48 \pm 0.02$ & $4.45 \pm 0.03$ & $4.40 \pm 0.02$ & $4.43 \pm 0.02$ & $4.56 \pm 0.03$ & $4.61 \pm 0.03$ & 4.49 \\
\hline MLBM & $4.26 \pm 0.02$ & $4.08 \pm 0.02$ & $4.12 \pm 0.02$ & $4.26 \pm 0.02$ & $4.30 \pm 0.02$ & $4.28 \pm 0.01$ & 4.22 \\
\hline MPBM & $4.41 \pm 0.02$ & $4.46 \pm 0.02$ & $4.36 \pm 0.02$ & $4.34 \pm 0.02$ & $4.48 \pm 0.02$ & $4.56 \pm 0.02$ & 4.44 \\
\hline $\begin{array}{l}\text { Average for } \\
\operatorname{Period}(\mathbf{P})\end{array}$ & 4.38 & 4.33 & 4.29 & 4.34 & 4.44 & 4.48 & \\
\hline \multicolumn{8}{|c|}{$\mathrm{CD}(\mathbf{0 . 0 5}) \quad \mathrm{T}=0.01 ; \mathrm{P}=0.02 ; \mathrm{TxP}=0.03$} \\
\hline \multicolumn{8}{|c|}{ SPC $(\log \mathrm{cfu} / \mathrm{g})$} \\
\hline Control & $4.26 \pm 0.02$ & $4.33 \pm 0.02$ & $4.38 \pm 0.04$ & $4.45 \pm 0.04$ & $4.48 \pm 0.03$ & $4.52 \pm 0.03$ & 4.40 \\
\hline MLBM & $4.04 \pm 0.02$ & $4.15 \pm 0.03$ & $4.26 \pm 0.04$ & $4.31 \pm 0.03$ & $4.37 \pm 0.03$ & $4.40 \pm 0.02$ & 4.25 \\
\hline MPBM & $4.15 \pm 0.02$ & $4.23 \pm 0.03$ & $4.32 \pm 0.04$ & $4.37 \pm 0.04$ & $4.40 \pm 0.03$ & $4.45 \pm 0.04$ & 4.32 \\
\hline $\begin{array}{l}\text { Average for } \\
\operatorname{Period}(\mathbf{P})\end{array}$ & 4.15 & 4.23 & 4.32 & 4.38 & 4.42 & 4.46 & \\
\hline \multicolumn{8}{|c|}{$T=0.02 ; P=0.03 ; T x P=0.05$} \\
\hline
\end{tabular}




\section{Lactobacilli count}

The changes in Lactobacilli count of control (C), MPBM and MLBM (T) stored at refrigeration temperature are illustrated in table 3. Lactobacilli count was significantly higher $(\mathrm{P}<0.05)$ in MPBM and MLBM (4.41 Log cfu/g and $4.26 \log \mathrm{cfu} / \mathrm{g}$ ) as compared to control $(4.48 \mathrm{log} \mathrm{cfu} / \mathrm{g})$ in the fresh product on $0 \mathrm{~d}$. The viable count increased to 4.45 , 4.46 and $4.08 \mathrm{log} \mathrm{cfu} / \mathrm{g}$ in control, MPBM and MLBM respectively up to $5^{\text {th }} \mathrm{d}$ of storage. Thereafter the viable count of Lactobacilli decreased on $15^{\text {st }} \mathrm{d}$ and again increased after $20^{\text {th }} \mathrm{d}$ of storage. The viable count for control, MPBM and MLBM were 4.61, 4.56 and 4.28 $\log \mathrm{cfu} / \mathrm{g}$ at the end of refrigeration storage. The LAB counts of buttermilk stored at $5 \pm 2$ ${ }^{0} \mathrm{C}$ delineated in table 3 , indicates spasmodic changes in count during storage of chhash. Statistically there was significant $(\mathrm{P}<0.05)$ difference in LAB count throughout the storage period. The interaction effect of the treatments with the period also showed significant changes. However the Lactobacilli count was appreciably lower by the antibacterial effect of Moringa than the control till the end of $25 \mathrm{~d}$ storage.

In case of experimental samples, the count remained almost stationary for some time (up to $10^{\text {th }} \mathrm{d}$ of storage), which may be attributed to the damage caused by the heat treatment given to experimental buttermilks. The increase in LAB population during extended period of storage may be ascribed to repair of the damaged cells and their subsequent growth or other lactic organisms(other than culture organism) surviving the heat shock given to buttermilk or may also be due to diauxy growth phenomena (Stainier et al., 1985).

\section{SPC count}

Standard Plate Count (SPC) is a collective enumeration of the overall microbiological quality of the product, after production and during its storage period. Standard Plate Count (SPC) gives the idea about the status of Moringa buttermilk in terms of its microbiological quality during storage. Therefore the SPC count of control as well as experimental samples packed in polyethylene terephthalate (PET) employed in this study was monitored at refrigeration temperature and the results obtained are presented in table 3.

The influence of period of storage at refrigeration temperature $\left(5 \pm 2{ }^{\circ} \mathrm{C}\right)$ on the SPC of control as well as experimental samples is shown in table 3. The SPC of buttermilks was significantly $(\mathrm{P}<0.05)$ influenced by storage period. During storage of buttermilks at refrigerated temperature also, a significant $(\mathrm{P} \leq 0.05)$ increase in SPC was observed up to $25^{\text {th }} \mathrm{d}$ of storage for Moringa buttermilks (MPBM and MLBM) and $20^{\text {th }} \mathrm{d}$ for C and thereafter the product was found unacceptable due to rejection by sensory panel. A steady rise in SPC was also observed by Rao (2003) in buttermilk during storage of thermized product when stored at refrigeration temperatures. However, no research has been reported in literature on the changes in SPC count of Moringa buttermilk during storage for comparison.

During the course of storage study, overall acceptability score of MLBM and MPBM decreased below minimum prescribed value on score card i.e. less than 6.0 at the end of 25 $\mathrm{d}$ whereas control was found acceptable till the $15^{\text {th }}$ day of storage only. Thus it can be concluded that both the Moringa based products prepared can be well acceptable up to $25 \mathrm{~d}$ of storage at $5 \pm 2{ }^{\circ} \mathrm{C}$ temperature after packaging in PET bottles.

\section{References}

Anwar, F., Zafar, N. and Rashid, U. 2006. Characterization of Moringa oleifera 
seed oil from drought and irrigated regions of Punjab. Grasasy Aceites, 57(2): 160-168.

AOAC, Official methods of analysis. 2004. 13th edition; Association of official analytical chemists, Washington DC.

Beyatli, Y. and Tunail, N. 1984. Relationship between lactic acid production and proteolytic activity of thermophilic lactic microorganisms isolated from yoghurt. J. Dairy Sci., 67: 63-67.

BIS. 1989. BIS Handbook of Food Analysis. SP: 18 (Part XI - Dairy Products. Bureau of Indian Standards, Manak Bhavan, New Delhi.

Chandan, R.C. 2006. History and consumption trends. In Manufacturing of yogurt and fermented milks. $1^{\text {st }}$ Edn. Blackwell Publishing Professional. Ames, Iowa, p.3-17.

Chander, R.C. 1989. In "Yoghurt: Nutritional and Health Properties". National Yoghurt Association. McLean. Virginia, U.S.A, p.25-78

Coppin, J.P.Y., Xu, H., and Chen. 2013. Determination of flavonoids by LC/MS and anti-inflammatory activity in Moringa oleifera. J. Functional Foods, 5(4): 1892-1899.

Dave, R.I. 1991. Standardizing conditions for pilot scale production and storage of buffalo milk dahi using selected strains of Streptococcus thermophilus. M.Sc. Thesis submitted to Gujarat Agril. University, Anand.

Deeth, H.C. and Fitz-Gerald, C.H. 1976. Lipolysis in dairy products: A review. Aust. J. Dairy Technol., 31: 53-59.

Fayed, E.O., Hagrass, A.E.A., Aly, A.A. and El-Samragy, Y.A. 1989. Use of Enterococci starter culture in the manufacture of yoghurt - like product. Cultured Dairy Products J., 24: 16-21.

Gawai, K.M. 2006. Formulations and properties of new functional dairy product- synbiotic dahi. M. Sc. Thesis submitted to Anand Agricultural University, Anand.

Indian Standards. 1961. IS: 1479, (Part-II. Methods of testing for dairy industry Part-II. Rapid examination of milk. Indian Standards Institution, New Delhi.

Kehagias, H.H., Konidas, P.E., Laskaris, H.I. and Kazazer, I.S. 1987. Fermentation of cows', goats' and ewes' milk by thermophilic acid producing culture. Episteme Kai Technologia Galaktos, 4: 43-47.

Kosikowaski, F. 1982. Cheese and Fermented milk Products. Kosikowaski F.V. Ed), Associates Publ., New York, p.568.

Makkar, H.P.S. and Becker, K. 1996. Nutrional value and whole and ethanol antinutritional components of extracted Moringa oleifera leaves. Animal Feed Sci. Technol., 63: 211-228.

Mistry, V.V. 2001. Fermented milks and cream. In: Marth E.H. and Steele J.L., Eds. Appl. Dairy Microbiol., Chapter 9, 2nd edition. Marcel Dekker, New York, p.301-325.

Mughal, M.H., Ali, G., Srivasta, P.S. and Iqbal, M. 1999. Improvement of drumstick (M. pterygosperma Gaertn) a unique source of food and medicine through tissue culture. Harmdad Med., 42: 37-42.

Nadeem, M.M., Abdullah, I., Hussain, S., Inayat, A., Javid, A. and Zahoor, Y. 2013. Antioxidant potential of Moringa oleifera leaf extract for the stabilisation of butter at refrigeration temperature. Czech. J. Food Sci., 31: 332-339.

Patel, M.T. 1984. Evaluation of the effects of methods of lactose hydrolysis and postincubation thermization in relation to manufacture and quality of stirred and frozen yoghurt. M.Sc. Thesis Submitted to Gujarat Agril. Univ., Gujarat.

Rao, A.V. 2003. Selected technological parameters for manufacture of chhash. M. Sc. Thesis submitted to Anand 
Agricultural University, Anand.

Stainier, R.Y., Adelberg, E.A. and Ingrahan, J.L. 1985. In: General Microbiology $4^{\text {th }}$ Ed. MacMillian Pub. Ltd., London, p. 256-258.

Steel, R.G.D. and Torrie, J.H. 1980. Principles and Procedures of Statistics. 2nd ed. New York: McGraw-Hill.

Tamime, A.Y. and Deeth, H.C. 1980. Yoghurt
-Technology and Biochemistry. $J$. Food. Prot., 43: 939-943.

Vanajakshi, V., Vijayendra, S.V.N., Varadaraj, M.C., Venkateswaran, G. and Agrawal, R. 2015. Optimization of a probiotic beverage based on Moringa leaves and beetroot. $L W T$ Food Sci. and Technol., 63(2): 12681273.

\section{How to cite this article:}

Binjan K. Patel, Sunil M. Patel, Zeel S. Modi and Suneeta V. Pinto. 2017. Shelf Life Studies of Buttermilk Supplemented with Moringa. Int.J.Curr.Microbiol.App.Sci. 6(4): 552-567. doi: https://doi.org/10.20546/ijcmas.2017.604.067 